\title{
THE CHARACTERISTICS OF THE HEALTH STATE POPULATION IN CENTRAL SERBIA
}

\author{
Radovanovic Snezana, ${ }^{1,2}$ Kocic Sanja, ${ }^{1,2}$ Vasiljevic Dragan, ${ }^{1,2}$ Radevic Svetlana, ${ }^{2}$ \\ Janicijevic Katarina, ${ }^{2}$ Mihailovic Natasa ${ }^{1}$ \\ ${ }^{1}$ Institute of Public health in Kragujevac, Serbia \\ ${ }^{2}$ Faculty of Medicine, University of Kragujevac, Serbia
}

Primljen/Received 26. 10. 2016. god.

Abstract: The aim of this study was to analyze the health status of the population in Central Serbia, in order to identify priority health problems. For data source, authors used reports about diseases, conditions and injuries, recorded in services for the health care of preschool children, services for school health, health care services for the adult population and services for the health care of women's health centers in Central Serbia in 2015. On the territory of Central Serbia, leading cause of morbidity in children of preschool and school age are diseases of the respiratory system. Cardiovascular diseases and respiratory diseases dominate in the structure of morbidity in the adult population, as well as high blood pressure as a single disease, while in the female population the most common are diseases of genitourinary tract.

Key words: health status, morbidity, Central Serbia.

\section{INTRODUCTION}

Assessment of the health status of the population is socio-medical procedure that allows us to obtain the objective picture of the health status of population using indicators.

More precisely, population health must be considered as the relation with indicators of the mortality, morbidity, disability, anthropometry and the quality of life.

Assessment of health status should be the first stage and a prerequisite for continued systematic and planned work to improve health, as well as the overall health system. Testing and evaluation of population health is not only the foundation of a modern health care planning and health services, but also a prerequisite for the planning and programming of work and development of health services on planning grounds, as well as the health promotion and further development of the health sys-
Prihvaćen /Accepted 25. 11. 2016. god.

tem. Today, almost all countries of the world are doing assessments of health, as a prerequisite and basis for the work on the reform of the health system (1).

\section{AIM}

The aim of this article was to analyze the health status of the population in Central Serbia, with the idea of identifying the priority health problems. This will ensure the implementation of the proper measures in addressing these problems.

\section{METHOD}

For data source, authors used the reports about diseases, conditions and injuries of services for the health care of preschool children, services for school health, health care services for the adult population and services for the health care of women's health centers of Central Serbia in 2015. The results are presented in tables.

\section{RESULTS AND DISCUSSION}

The population group of preschool children belongs to the birth time up to 6 years age. The proper attention should be paid in order to protect the health of this population group, not only because of special sensitivity to the effects of different factors, which may endanger their health, but also due to the fact that poor health and unhealthy lifestyles in childhood may result in poor health throughout their lives, which for the company means the health, financial and social consequences (2).

In health care services for preschool children in the territory of Central Serbia were registered in 2015, 138074 illnesses. Five of the most common groups of diseases are diseases of the respiratory system with 
$50.5 \%$, followed by the factors influencing health status and contact with health services with $17.2 \%$, diseases of the ear and mastoid process with $5.5 \%$ and symptoms, signs and abnormal clinical and laboratory findings to $7.4 \%$ (Table 1). The leading diagnoses in a group of diseases of the respiratory system are acute inflammation of the throat and tonsils (43.2\%) and upper respiratory tract infections $(27.5 \%)$. These diseases are a short stream of good forecast and with greater socio-medical significance. Diseases of middle ear and mastoid disease is the most common diagnosis from a group of diseases of the ear and mastoid process with a share of $93.4 \%$ (Table2).

Population group of school children and youth belonging to school children aged 7 to 14 years and school youth (teenagers) from 15 to 19 years. School children and youth indicators of health are considered as the healthiest of all other age groups. However, this period of life is characterized by rapid sexual and psychosocial development as well as the risk for the formation of various risk behaviors, which may endanger the health at given time and/or later in life (3).

The most common causes of morbidity of school children on the territory of Central Serbia, in 2015 were respiratory diseases, accounting for $38.6 \%$ of the total morbidity.

The most common diagnosis in this group of diseases was acute inflammation of the throat and tonsils, which makes $42.9 \%$ of all diagnoses of diseases of the respiratory system.

Table 1. Leading groups of diseases in health care services for preschool children on the territory of Central Serbia, in 2015.

\begin{tabular}{|l|c|c|}
\hline \multicolumn{1}{|c|}{ GROUP OF DISEASE } & Number & \% \\
\hline Respiratory system diseases & 69791 & 50.5 \\
\hline Factors influencing of health status and contact with health service & 23724 & 17.2 \\
\hline Symptoms, signs and abnormal clinical and laboratory findings & 10249 & 7.4 \\
\hline Diseases of the ear and mastoid process & 7620 & 5.5 \\
\hline Other diseases & 26690 & 19.3 \\
\hline Total & 138074 & 100 \\
\hline
\end{tabular}

Table 2. The main diseases in health care services for preschool children in the territory of Central Serbia, in 2015.

\begin{tabular}{|c|l|r|r|}
\hline \multicolumn{2}{|c|}{ GROUP OF DISEASE } & Number & \% \\
\hline \multicolumn{2}{|c|}{ Respiratory system diseases } & 69791 & 100 \\
\hline 1 & Acute inflammation of the throat and the tonsils & 30134 & 43.2 \\
\hline 2 & Upper respiratory tract infections & 19174 & 27.5 \\
\hline 3 & Acute bronchitis and bronchiolitis & 10857 & 15.6 \\
\hline 4 & Other diseases & 9626 & 13.7 \\
\hline Factors influencing of health status and contact with health service & 23724 & 100 \\
\hline 1 & Persons who seeking of health services for examination and testing & 11934 & 50.3 \\
\hline 2 & Persons in health services for other reasons & 8972 & 37.8 \\
\hline 3 & Other persons of potentially compromised of health contagious disease & 2029 & 8.6 \\
\hline 4 & Other diseases & 789 & 3.3 \\
\hline Symptoms, signs and abnormal clinical and laboratory findings & 10249 & 100 \\
\hline 1 & Other symptoms, signs and laboratory findings & 4858 & 47.4 \\
\hline 2 & Febrile conditions & 4539 & 44.3 \\
\hline 3 & Pain in the abdomen and pelvis & 801 & 7.8 \\
\hline Diseases of the ear and mastoid process & 7620 & 100 \\
\hline 1 & Diseases of middle ear and mastoid disease & 7121 & 93.4 \\
\hline 2 & Other diseases of middle ear and mastoid disease & 493 & 6.5 \\
\hline 3 & Other diseases & 6 & 0.07 \\
\hline
\end{tabular}


Table 3. Leading groups of diseases in the services for school health on the territory of Central Serbia, in 2015.

\begin{tabular}{|l|c|c|}
\hline \multicolumn{1}{|c|}{ GROUP OF DISEASE } & Number & \% \\
\hline Respiratory system diseases & 61228 & 38.6 \\
\hline Factors influencing of health status and contact with health service & 45771 & 28.9 \\
\hline Symptoms, signs and abnormal clinical and laboratory findings & 11163 & 7.0 \\
\hline Skin and subcutaneous tissue disorders & 6355 & 4.0 \\
\hline Other diseases & 34117 & 21.5 \\
\hline Total & 158634 & 100 \\
\hline
\end{tabular}

Table 4. The main diseases in health care services for school children on the territory of Central Serbia, in 2015.

\begin{tabular}{|c|l|r|r|}
\hline \multicolumn{2}{|c|}{ GROUP OF DISEASE } & Number & \% \\
\hline \multicolumn{2}{|c|}{ Respiratory system diseases } & 61228 & 100 \\
\hline 1 & Acute inflammation of the throat and the tonsils & 26255 & 42.9 \\
\hline 2 & Upper respiratory tract infections & 12236 & 20.0 \\
\hline 3 & Acute bronchitis and bronchiolitis & 6473 & 10.5 \\
\hline 4 & Other diseases & 16264 & 26.6 \\
\hline Factors influencing of health status and contact with health service & 45771 & 100 \\
\hline 1 & Persons who seeking health services for examination and testing & 35229 & 77 \\
\hline 2 & Persons in health services for other reasons & 6929 & 15.1 \\
\hline 3 & Other persons of potentially compromised of health contagious disease & 3582 & 7.8 \\
\hline 4 & Other diseases & 31 & 0.06 \\
\hline Symptoms, signs and abnormal clinical and laboratory findings & 11163 & 100 \\
\hline 1 & Other symptoms, signs and laboratory results & 6446 & 57.7 \\
\hline 2 & Febrile conditions & 2693 & 24.1 \\
\hline 3 & Pain in the abdomen and pelvis & 2024 & 18.4 \\
\hline 4 & Other diseases & 601 & 10.1 \\
\hline Skin & and subcutaneous tissue disorders & 6355 & 100 \\
\hline 1 & Other diseases of skin and subcutaneous tissue & 4499 & 70.8 \\
\hline 2 & Infections of skin and subcutaneous tissue & 1856 & 29.2 \\
\hline
\end{tabular}

Upper respiratory tract infections are on the second place among the leading diagnoses of acute bronchitis and bronchiolitis. This acute disease has a short course, a good prognosis without greater social and medical importance. In second place are the factors influencing health status and contact with health services with $28.9 \%$ and third in total registered morbidity of this population group - the symptoms, signs and abnormal clinical and laboratory findings with 7\%. Disorders of skin and subcutaneous tissues are in fourth place in the overall morbidity of school children (Table 3, Table 4).

Women's health is due to the high sensitivity of this population group and the fact that women take care of their own health but also the health of their children, parents and other family members, certainly of particular importance. Women's health involves an emotional, social and physical well-being, and is determined by the social, political and economic context in which women live, as well as the biological aspect. Women's health is not just her personal problem but also a problem of respective societies and the international community. Improving the health and quality of life of women has the very positive impact on the entire family (4).

In health care services for women in the territory of Central Serbia in 2015, more than half of the total mortality $(60.7 \%)$ is a group of diseases of urinary tract. Factors influencing health status and contact with health services are represented with $27.1 \%$ of the morbidity of this service. The total morbidity of this service showed that $3.7 \%$ of a group had problems concerning - preg- 
Table 5. Leading groups of diseases in the area of women's health care on the territory of Central Serbia, in 2015.

\begin{tabular}{|l|c|c|}
\hline \multicolumn{1}{|c|}{ GROUP OF DISEASE } & Number & \% \\
\hline Diseases of the genitourinary system & 29981 & 60.7 \\
\hline Factors influencing of health status and contact with health service & 13395 & 27.1 \\
\hline Tumors & 1968 & 4.0 \\
\hline Pregnancy, childbirth and puerperium & 1836 & 3.7 \\
\hline Othr diseases & 2240 & 4.5 \\
\hline Total & 49420 & 100 \\
\hline
\end{tabular}

Table 6. The main diseases in health care services for women on the territory of Central Serbia, in 2015.

\begin{tabular}{|c|l|r|r|}
\hline \multicolumn{2}{|c|}{ GROUP OF DISEASE } & Number & \% \\
\hline \multicolumn{2}{|l|}{ Diseases of the genitourinary system } & 29981 & 100 \\
\hline 1 & Cervicitis uterii & 9363 & 31.2 \\
\hline 2 & Other inflammation of female pelvic organs & 6204 & 20.7 \\
\hline 3 & The menstrual disorders & 3325 & 11.1 \\
\hline 4 & Other diseases & 11000 & 36.7 \\
\hline Factors influencing of health status and contact with health service & 13395 & 100 \\
\hline 1 & Persons who seeking of health services for examination and testing & 9680 & 73.3 \\
\hline 2 & Care and inspection after childbirth & 1357 & 10.1 \\
\hline 3 & Other diseases & 2358 & 17.6 \\
\hline Tumors & 1968 & 100 \\
\hline 1 & Leiomioma uteri & 671 & 34.0 \\
\hline 2 & Neoplasmus benigna ovarii & 479 & 24.3 \\
\hline 3 & Malignant tumors of connective and soft tissue & 214 & 10.9 \\
\hline 4 & Other diseases & 604 & 30.7 \\
\hline Pregnancy, childbirth and puerperium & 1836 & 100 \\
\hline 1 & Other complications of pregnancy and childbirth & 578 & 31.5 \\
\hline 2 & $\begin{array}{l}\text { Complications in confinements and other conditions which complicate } \\
\text { pregnancy and childbirth }\end{array}$ & 394 & 21.5 \\
\hline 3 & Other diseases & 972 & 53 \\
\hline
\end{tabular}

nancy, childbirth and confinements. The most significant group due to chronic course, the possibilities of secondary prevention and high participation in mortality, make tumors, whose share in the total morbidity services for the health care of the women in Central Serbia with $4.5 \%$ (Table 5, Table 6).

In general medicine of health of Central Serbia, in 2015, a total of 459055 illnesses were recorded. The leading place in the structure of morbidity in the general medicine on the territory of Central Serbia in 2015 occupying diseases of the circulatory system with $19.8 \%$, which, like other chronic, mass, non-communicable diseases to progressively flow often lead to absenteeism, disability and shortening the length of the quality of life.
Leading diagnoses within this group of diseases is essential (primary) arterial hypertension (67\%). In second place are the diseases of the respiratory system to the proportion of the total morbidity of $19.4 \%$, which have the higher socio-medical significance, because it is an acute disease with a short course and the possibility of effective treatment. The leading diagnoses in this group of diseases are acute inflammation of the throat and tonsils, acute bronchitis/bronchiolitis and upper respiratory tract infections. Factors' influencing health status and contact with health services are ranked third with a share of $8.8 \%$. Diseases of the musculoskeletal system and connective tissue are represented with $7.9 \%$ of morbidity in general medicine services. A group of diseases of urinary tract is in fifth place with a 
Table 7. The main diseases in health care services for women on the territory of Central Serbia, in 2015.

\begin{tabular}{|l|c|c|}
\hline \multicolumn{1}{|c|}{ GROUP OF DISEASE } & Number & \% \\
\hline Circulatory system diseases & 90798 & 19.8 \\
\hline Respiratory system diseases & 88955 & 19.4 \\
\hline Factors influencing of health status and contact with health service & 40498 & 8.8 \\
\hline Diseases of the musculoskeletal system and connective tissue & 36191 & 7.9 \\
\hline Diseases of the genitourinary system & 33928 & 7.4 \\
\hline Other diseases & 168685 & 36.7 \\
\hline Total & 459055 & 100 \\
\hline
\end{tabular}

Table 8. The main diseases in general medicine on the territory of Central Serbia, in 2015.

\begin{tabular}{|c|l|r|r|}
\hline \multicolumn{1}{|c|}{ GROUP OF DISEASE } & Number & \% \\
\hline \multicolumn{2}{|c|}{ Circulatory system diseases } & 90798 & 100 \\
\hline 1 & Essential (primary) arterial hypertension & 60799 & 67 \\
\hline 2 & Disorders of the conduction system of the heart and heart arrhythmias & 7471 & 8.2 \\
\hline 3 & Other ischemic heart diseases & 6467 & 7.1 \\
\hline 4 & Other diseases & 16061 & 17.7 \\
\hline \multicolumn{2}{|c|}{ Respiratory system diseases } & 88955 & 100 \\
\hline 1 & Acute inflammation of the throat and tonsils & 38832 & 43.7 \\
\hline 2 & Upper respiratory tract infections & 15172 & 17.1 \\
\hline 3 & Acute bronchitis and bronchiolitis & 13199 & 14.8 \\
\hline 4 & Other disesases & 21752 & 24.5 \\
\hline Factors influencing of health status and contact with health services & 40498 & 100 \\
\hline 1 & Persons who of seeking health services for examination and testing & 25209 & 62.3 \\
\hline 2 & Other persons of potentially compromised of health contagious disease & 8602 & 21.2 \\
\hline 3 & Persons in health services for other reasons & 5836 & 14.4 \\
\hline 4 & Other diseases & 851 & 2.1 \\
\hline Diseases of the musculoskeletal system and connective tissue & 36191 & 100 \\
\hline 1 & Other diseases of the back & 20211 & 55.9 \\
\hline 2 & Degenerative diseases of the joints & 6218 & 17.1 \\
\hline 3 & Inflammation of the joints & 2621 & 7.2 \\
\hline 4 & Other diseases & 7141 & 19.7 \\
\hline Diseases of the genitourinary system & 33928 & 100 \\
\hline 1 & Inflammation of the bladder & 20343 & 60 \\
\hline 2 & Prostatic hyperplasia & 4440 & 13.1 \\
\hline 3 & Other diseases of urinary system & 5934 & 9.5 \\
\hline 4 & Other diseases & & 17.5 \\
\hline
\end{tabular}

share of $7.4 \%$. Within this group inflammation of the bladder with an incidence of $60 \%$ is the most common diagnosis in an adult population (Table 7, Table 8).

Similar results were found in our neighborhood countries. In Croatia in 2015, in the structure of morbidity of the adult population were the most common respiratory diseases and diseases of the heart and blood vessels. For children of preschool and school age usually are diseases of the respiratory system, followed by infectious and parasitic diseases, ear, skin and subcutaneous tissue. The most common reasons why women went to the gynecological clinic and used the services of chosen gynecologist within primary health care of women in Croatia in 2015 were diseases of the urinary 
and sexual organs, pregnancy, childbirth and confinement, followed by tumors, infectious and parasitic diseases (5).

\section{CONCLUSION}

On the territory of Central Serbia, one leading cause of illness in children of preschool and school age are diseases of the respiratory system. In the structure of morbidity in the adult population are dominated cardiovascular diseases and respiratory diseases, while the high blood pressure is taken as a single disease.

Among females, the most common diseases are diseases of genitourinary tract. Intensifying promotio- nal and preventive measures and activities, as well as educating the population of risk factors and diseases prevention is certainly the priority, in order to achieve improvement and preservation of health of the population in Central Serbia.

\section{CONFLICT OF INTEREST}

The authors declare that there is no conflict of interest.

\section{Source of Funding}

There were no external funding source for this study.

\title{
Sažetak
}

\section{KARAKTERISTIKE ZDRAVSTVENOG STANJA STANOVNIŠTVA CENTRALNE SRBIJE}

\author{
Radovanović Snežana, ${ }^{1,2}$ Kocić Sanja, ${ }^{1,2}$ Vasiljević Dragan, ${ }^{1,2}$ Radević Svetlana, \\ Janićijević Katarina, ${ }^{2}$ Mihailović Nataša ${ }^{1}$ \\ ${ }^{2}$ Fakultet medicinskih nauka, Univerzitet u Kragujevcu, Srbija
}

Cilj rada je analiza zdravstvenog stanja stanovništva u Centralnoj Srbiji radi identifikacije prioritetnih zdravstvenih problema. Kao izvor podataka korišćeni su Izveštaji o oboljenjima, stanjima i povredama - službi za zdravstvenu zaštitu predškolske dece, službi za zdravstvenu zaštitu školske dece, službi za zdravstvenu zaštitu odraslog stanovništva, službi za zdravstvenu zaštitu radno aktivnog stanovništva i službi za zdravstvenu zaštitu žena Domova zdravlja Centralne Srbije

\section{REFERENCES}

1. Simić S. Social Medicine. Belgrade: Faculty of Medicine University of Belgrade Publ, 2012.

2. Public health of Sumadija district. Analytical Study 1998 - 2008 Kragujevac: Public Health of Institute in Kragujevac Publ, 2009.

\author{
Correspodence to/ Autor za korespodenciju \\ Snezana Radovanovic \\ Nikola Pašić 1, 34000 Kragujevac \\ tel: $034 / 504532$; \\ mob: 064/1509414 \\ fax: 034/331344 \\ e-mail: jovanarad@yahoo.com
}

za 2015. godinu. Na teritoriji centralne Srbije vodeći uzrok oboljevanja kod dece predškolskog i školskog uzrasta su bolesti sistema za disanje. U strukturi morbiditeta kod odraslog stanovništva dominiraju bolesti sistema krvotoka i bolesti sistema za disanje, dok su u populaciji žena najzastupljenije bolesti mokraćno-polnog sistema.

Ključne reči: zdravstveno stanje, morbiditet, centralna Srbija.

3. Radovanovic S, Kocic S, Djokic D, Milisavljevic M, Popovic P, Zivanovic S. The health status of school children and youth in Sumadija district. Public Health. 2010; 6: 1-7.

4. Gajovic G, Radovanovic S, Kocic S, Djokić D, Popovic $\mathrm{P}$, Radevic S. Characteristics of the health status of women in the territory of Šumadija district. Public Health 2011; 3: 33-7.

5. The Croatian Health Service Year book. Zagreb: Croatian AOD of Public Health - Croatian Institute of Public Health Publ, 2015. http://www.hzjz.hr/publikacije/statisticki-ljetopis/. 